\title{
Kazachstania aquatica sp. nov. and Kazachstania solicola sp. nov., novel ascomycetous yeast species
}

\author{
Correspondence \\ Feng-Yan Bai \\ baify@sun.im.ac.cn
}

\author{
Zuo-Wei Wu ${ }^{1,2}$ and Feng-Yan Bai ${ }^{1}$ \\ ${ }^{1}$ Systematic Mycology and Lichenology Laboratory, Institute of Microbiology, Chinese Academy \\ of Sciences, Beijing 100080, China \\ ${ }^{2}$ Graduate school of the Chinese Academy of Sciences, Beijing 100039, China
}

\begin{abstract}
The unidentified strains AS $2.0706^{\top}$, preserved in the China General Microbiological Culture Collection Center (CGMCC), Academia Sinica, Beijing, China, and CBS $6904^{\top}$, preserved in the Centraalbureau voor Schimmelcultures (CBS), Utrecht, The Netherlands, were shown to represent two novel ascomycetous yeast species of the genus Kazachstania by $18 \mathrm{~S}$ rDNA, internal transcribed spacer (ITS) region (including 5•8S rDNA) and 26S rDNA D1/D2 domain sequence analysis and electrophoretic karyotype comparison. The names Kazachstania aquatica sp. nov. and Kazachstania solicola sp. nov. are proposed for strains AS $2.0706^{\top}$ and CBS $6904^{\top}$, respectively. Phylogenetically, the two novel species are closely related to Kazachstania aerobia, Kazachstania servazzii and Kazachstania unispora.
\end{abstract}

Recent studies on the molecular taxonomy of yeasts have shown that identification of yeast species based on morphological and physiological criteria is often problematic. In order to authenticate the identification of catalogued yeast strains preserved in the China General Microbiological Culture Collection Center (CGMCC), strains that lacked molecular data were selected for rRNA gene sequencing. One strain, AS $2.0706^{\mathrm{T}}$, which was originally labelled as Torulopsis sp., was found to represent a novel ascomycetous yeast species based on rRNA gene sequence comparisons. This novel species is closely related to three previously described Kazachstania species and to strain CBS $6904^{\mathrm{T}}$ as revealed by sequence analysis of the small-subunit (18S) rRNA gene, the internal transcribed spacer (ITS) region (including the $5 \cdot 8 \mathrm{~S}$ rRNA gene) and the large-subunit (26S) rRNA gene D1/D2 domain. Strain CBS $6904^{\mathrm{T}}$, which was assigned to Saccharomyces dairenensis (Naumovia dairenensis) by VaughanMartini \& Martini (1998), has recently been shown to represent a separate species by Lu et al. (2004). The novel species represented by strains AS $2.0706^{\mathrm{T}}$ and CBS $6904^{\mathrm{T}}$ are described in the present study.

Published online ahead of print on 13 May 2005 as DOI 10.1099/ ijs.0.63675-0.

Abbreviation: ITS, internal transcribed spacer.

The GenBank/EMBL/DDBJ accession numbers for the 18S rRNA, ITS and 26S rRNA gene sequences of Kazachstania aquatica sp. nov. and K. solicola sp. nov. are AY881650-AY881652.

A more detailed phylogenetic tree based on 18S rRNA gene sequence analysis is available as supplementary material in IJSEM Online.
Strain AS $2.0706^{\mathrm{T}}$ was isolated from the wastewater of a paper mill in north-east China. The type strain of Kazachstania aerobia (AS $2.2384^{\mathrm{T}}$ ) was obtained from the CGMCC. Strain CBS $6904^{\mathrm{T}}$ and the type strains of Kazachstania unispora (CBS $398^{\mathrm{T}}$ ) and Kazachstania servazzii $\left(\mathrm{CBS} 4311^{\mathrm{T}}\right)$ were obtained from the Centraalbureau voor Schimmelcultures (CBS), Utrecht, The Netherlands.

Most of the morphological, physiological and biochemical characteristics were examined according to standard methods (Yarrow, 1998). Assimilation of nitrogen compounds was investigated on solid media with starved inocula (Nakase \& Suzuki, 1986). Extraction, purification and identification of ubiquinones were carried out according to Yamada \& Kondo (1973).

Nuclear DNA was extracted by the method of Makimura et al. (1994). The DNA fragment covering the ITS region (including $5 \cdot 8 \mathrm{~S}$ rDNA) and the large-subunit rDNA D1/D2 domain was amplified and sequenced according to Lu et al., 2004. The small-subunit rRNA gene was amplified and sequenced according to Sugita \& Nakase (1999). Molecular phylogenetic analysis was performed by the methods described by Bai et al. (2002). Reference sequences were retrieved from GenBank under the accession numbers indicated in the trees.

Intact yeast chromosomal DNA was prepared by the method of Bai et al. (2000). Pulsed-field gel electrophoresis (PFGE) was performed according to $\mathrm{Lu}$ et al. (2004). 


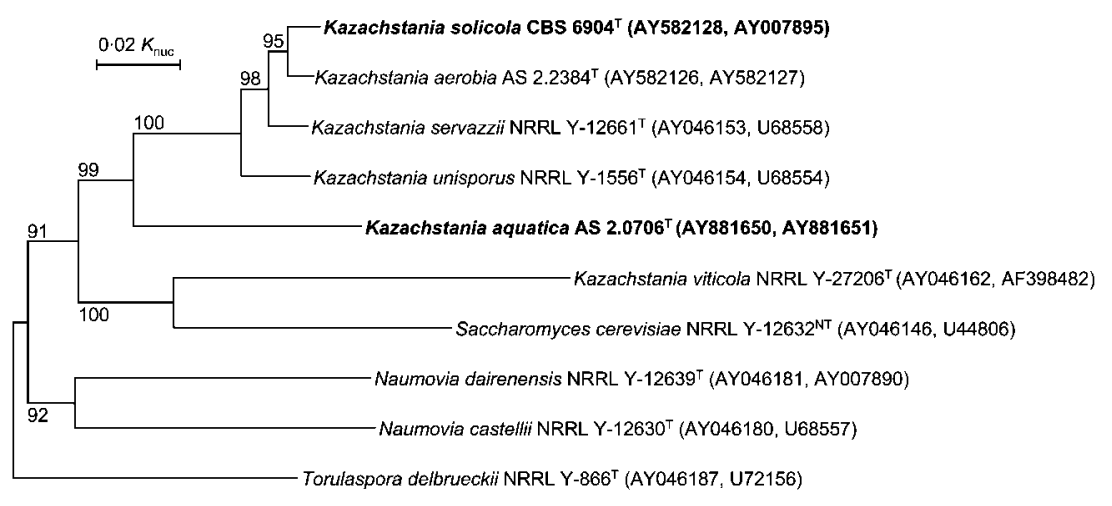

Fig. 1. Phylogenetic tree drawn from neighbour-joining analysis of the combined sequences of ITS (including 5.8S rDNA) region and 26S rDNA D1/D2 domain sequences, depicting the relationships of Kazachstania aquatica sp. nov. and Kazachstania solicola sp. nov. with closely related taxa. Bootstrap percentages over $50 \%$ from 1000 bootstrap replicates are shown.

\section{Sequence analyses}

The close phylogenetic relationship of strain CBS $6904^{\mathrm{T}}$ with $K$. aerobia, K. servazzii and K. unispora, based on D1/D2 and ITS sequence analysis, has been shown by Lu et al. (2004). The position of strain AS $2.0706^{\mathrm{T}}$ was not clearly resolved in the tree drawn from the sequences of D1/D2 (data not shown). In trees drawn from the combined ITS (including 5.8S rDNA) and D1/D2 regions (Fig. 1) and from the small-subunit rDNA (see Supplementary Fig. S1 in IJSEM Online), the strain was located in a basal position relative to a small clade containing strain CBS $6904^{\mathrm{T}}$ and three previously described Kazachstania species.

Strain AS $2.0706^{\mathrm{T}}$ differed from strain CBS $6904^{\mathrm{T}}, K$. aerobia, K. servazzii and K. unispora by $3 \%$ in the D1/D2 regions and by more than 20 nucleotides in the ITS region. Strain CBS $6904^{\mathrm{T}}$ and K. aerobia had identical D1/D2 sequences, but they differed by 18 base substitutions and 10 indels (6.7\% mismatch) in the ITS region. Strain CBS $6904^{\mathrm{T}}$ differed from $K$. servazzii and K. unispora by two and four base substitutions, respectively, in the D1/D2 region and by 21 substitutions and 13 indels $(8 \cdot 1 \%)$ and by 34 substitutions and 24 indels $(13 \cdot 8 \%)$, respectively, in the ITS region ( $\mathrm{Lu}$ et al., 2004).

\section{Electrophoretic karyotyping}

The electrophoretic karyotypes of strains AS $2.0706^{\mathrm{T}}$ and CBS $6904^{\mathrm{T}}$ bore a superficial resemblance to those of the phylogenetically closely related species $K$. aerobia, K. servazzii and $K$. unispora (Fig. 2). Approximately 9 (600 to $2200 \mathrm{~kb}$ ) and 11 (585 to $2200 \mathrm{~kb}$ ) bands were resolved for AS $2.0706^{\mathrm{T}}$ and CBS $6904^{\mathrm{T}}$, respectively. As wider bands or bands with higher intensities may correspond to doublets or triplets, the actual number of chromosomes may be higher. The patterns were nonetheless sufficiently distinct to differentiate the species from one another. Although strain CBS $6904^{\mathrm{T}}$ was more closely related to $K$. aerobia than to $K$. servazzii and $K$. unispora based on the sequence data, its chromosomal banding profile had more pronounced differences from that of $K$. aerobia compared with $K$. servazzii and K. unispora (Fig. 2).

\section{Taxonomy}

On the basis of rRNA sequences and chromosomal DNA banding profiles, we regard strains AS $2.0706^{\mathrm{T}}$ and CBS $6904^{\mathrm{T}}$ as representing two novel species of the genus Kazachstania and propose the names Kazachstania aquatica sp. nov. and Kazachstania solicola sp. nov., respectively. Phenotypically, K. aquatica sp. nov. is similar to K. unispora, the two differing slightly in the assimilation reactions of trehalose and ethanol. K. solicola is similar to K. servazzii, but the two differ in their responses in the ethanol assimilation test (Table 1).

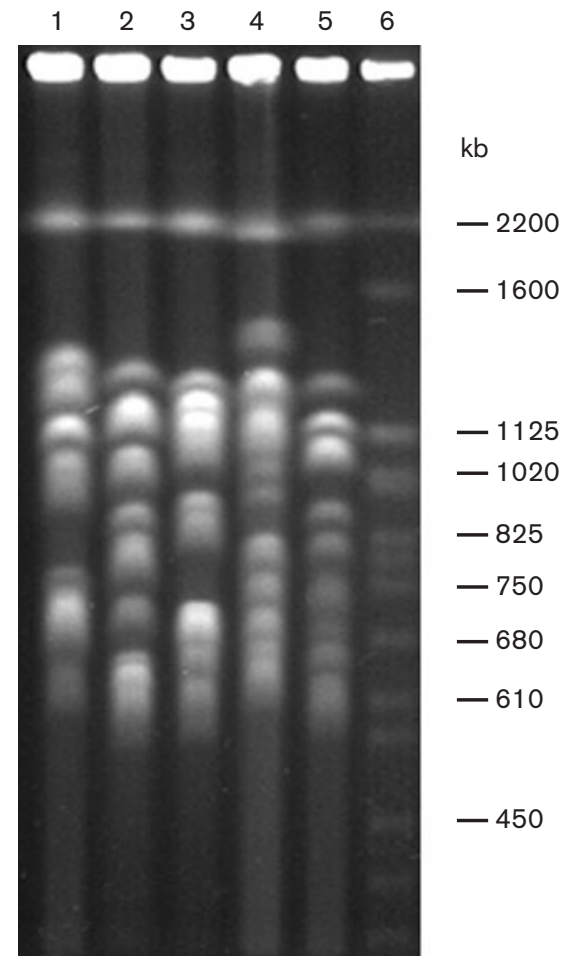

Fig. 2. Electrophoretic karyotypes. Lanes: 1, Kazachstania aquatica sp. nov. AS $2.0706^{\top} ; 2$, Kazachstania unispora CBS $398^{\top}$; 3, Kazachstania servazzii CBS $4311^{\top}$; 4, Kazachstania aerobia AS $2.2384^{\top}$; 5 , Kazachstania solicola sp. nov. CBS $6904^{\top} ; 6$, Saccharomyces cerevisiae YNN 295. 
Table 1. Physiological characteristics that differentiate Kazachstania aquatica sp. nov. and Kazachstania solicola sp. nov. from closely related species

+ , Positive; W, weak; D, delayed positive; -, negative.

\begin{tabular}{|c|c|c|c|c|c|}
\hline Assimilation of: & K. aquatica & K. solicola & K. aerobia & K. unispora & K. servazzii \\
\hline Trehalose & $\mathrm{W}, \mathrm{D}$ & $\mathrm{D}$ & + & - & $\mathrm{D}$ \\
\hline D-Ribose & - & $\mathrm{D}$ & $\mathrm{D}$ & - & $\mathrm{W}, \mathrm{D}$ \\
\hline D-Glucosamine & - & $\mathrm{D}$ & - & - & - \\
\hline Ethanol & $\mathrm{W}, \mathrm{D}$ & - & - & + & + \\
\hline Glycerol & - & $\mathrm{D}$ & + & - & $\mathrm{D}$ \\
\hline D-Mannitol & - & - & $\mathrm{D}$ & - & - \\
\hline Succinic acid & - & - & $\mathrm{W}$ & - & - \\
\hline Ethylamine & + & - & - & + & - \\
\hline L-Lysine & + & - & + & + & - \\
\hline Cadaverine & + & - & - & + & - \\
\hline
\end{tabular}

ITS sequencing can be used to differentiate the novel species from their close relatives, although the amount of intraspecific variation will remain unknown until other strains are available. However the following data suggest that ITS sequences are generally conserved within Kazachstania species. Two strains of $K$. aquatica sp. nov. with slightly different karyotypes have been shown to have identical ITS sequences (Lu et al., 2004). Kurtzman \& Robnett (2003) examined two strains of $K$. unispora and found them to have identical ITS sequences. The ITS sequences of two additional strains of K. unispora (GenBank accession nos AF321542 and AF455430) differ from that of the type strain by only one indel. Nevertheless, since the D1/D2 sequences of $K$. solicola sp. nov. and $K$. aerobia are identical and only one strain is available for the former at present, DNA-DNA hybridization would certainly be helpful to justify the establishment of this novel species.

The genus Kazachstania was redefined recently based on multigene sequencing. A relatively large number of species in an only moderately supported clade resolved from the combined sequences of six regions or genes were assigned into the genus (Kurtzman, 2003; Kurtzman \& Robnett, 2003). This was apparently a provisional treatment. The phylogenies of these yeasts resolved from the sequences of the small-subunit rRNA gene and other single genes were not congruent with that resolved from the combined gene analysis (James et al., 1997; Kurtzman \& Robnett, 2003; Mikata et al., 2001; Śpírek et al., 2003). The addition of novel species may help to reclassify the species in this genus into more homogeneous groups. The two novel species described in the present study and the three already described species, K. aerobia, K. servazzii and K. unispora, formed a strongly supported clade in the trees based on the small-subunit rRNA and combined ITS and D1/D2 sequences (see Supplementary Fig. S1 in IJSEM Online and Fig. 1). Interestingly, the species in this group have similar karyotypes (Fig. 2), as do those of Saccharomyces sensu stricto (Fischer et al., 2000; Vaughan-Martini et al., 1993).

\section{Latin diagnosis of Kazachstania aquatica Bai \& Wu sp. nov.}

In medio liquido YM post dies 3 ad $25^{\circ} \mathrm{C}$, cellulae globosae vel subglobosae, 3.7-6.2 $\times 5 \cdot 0-7 \cdot 5 \mu \mathrm{m}$, singulae, binae et adhaerentes. Per gemmationem multipolarem reproducentes. Post 1 mensem sedimentum formatur. In agaro YM post 1 mensem ad $25^{\circ} \mathrm{C}$, butyrosa, cremea, initida, verrucosa, glabra cum radiatis, margo undulato. In agaro farinae Zea mays post dies 7, pseudohyphae nullae. Asci inconjugatio fiunt. Ascosporae globosae, 1 in quoque asco.

Glucosum et galactosum fermentantur at non sucrosum, maltosum, lactosum nec raffinosum. Glucosum, galactosum, trehalosum (infirme, lente), ethanolum (infirme, lente) assimilantur at non L-sorbosum, sucrosum, maltosum, cellobiosum, lactosum, melibiosum, raffinosum, melezitosum, inulinum, amylum solubile, D-xylosum, L-arabinosum, Darabinosum, D-ribosum, L-rhamnosum, D-glucosaminum, methanolum, glycerolum, erythritolum, ribitolum, galactitolum, D-mannitolum, D-glucitolum, methyl $\alpha$-D-glucosidum, salicinum, acidum DL-lacticum, acidum succinicum, acidum citricum, inositolum nec hexadecanum. Ammonium sulfatum, ethylaminum, L-lysinum et cadaverinum assimilantur at non natrum nitrosum nec kalium nitricum. Ad crescentiam vitaminae externae necessariae sunt. Maxima temperatura crescentiae: $37^{\circ} \mathrm{C}$. Materia amyloidea iodophila non formantur. Diazonium caeruleum B non respondens. Ureum non hydrolysatur. Systema coenzymatis Q-6 adest. Typus depositus in collectione China General Microbiological Culture Collection Center, Academia Sinica (AS 2.0706 ${ }^{\mathrm{T}}$ ).

\section{Description of Kazachstania aquatica Bai \& Wu sp. nov.}

Kazachstania aquatica (L. fem. adj. aquatica aquatic, referring to the source of the type strain).

In YM broth (Yarrow, 1998), after 3 days at $25^{\circ} \mathrm{C}$, the cells are globose to subglobose, $3 \cdot 7-6 \cdot 2 \times 5 \cdot 0-7 \cdot 5 \mu \mathrm{m}$ and occur singly, in pairs or in groups (Fig. 3 ). Budding is multilateral. 

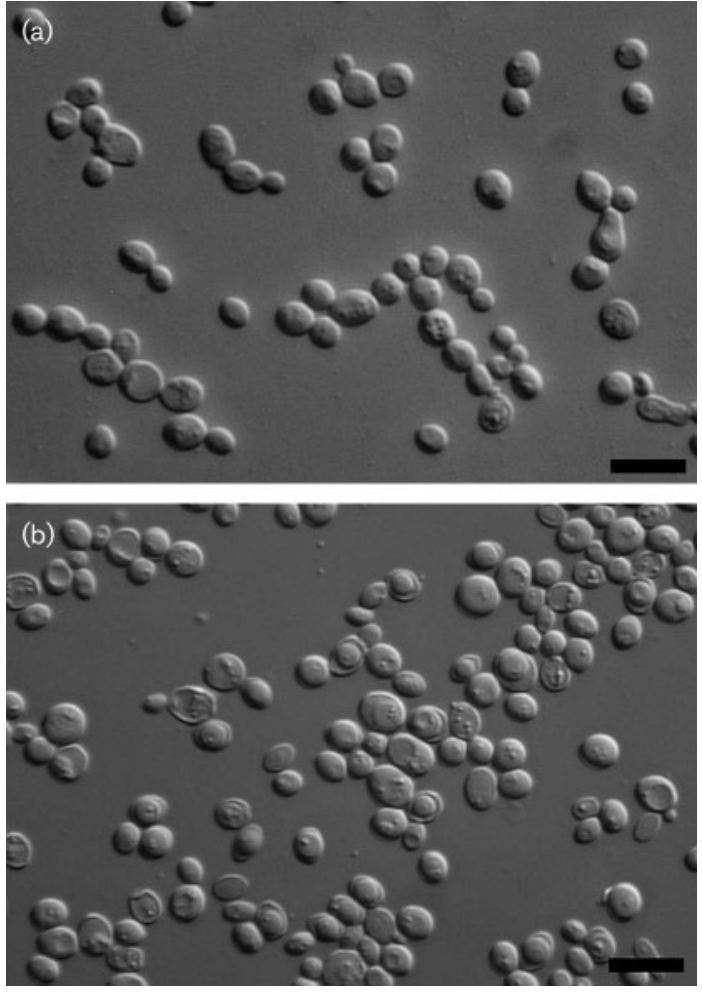

Fig. 3. Kazachstania aquatica sp. nov. AS $2.0706^{\top}$. (a) Vegetative cells grown in YM broth for 3 days at $25^{\circ} \mathrm{C}$. (b) Asci formed on acetate agar after 5 days at $25^{\circ} \mathrm{C}$. Bars, $10 \mu \mathrm{m}$.

After 1 month at $25^{\circ} \mathrm{C}$, sediment is present. On YM agar (Yarrow, 1998), after 1 month at $25^{\circ} \mathrm{C}$, the streak culture is butyrous, cream-coloured, raised, glossy, verruciform and smooth with faint striations; the margin is undulating. In Dalmau plate culture on cornmeal agar, pseudohyphae are not formed. Sporulation was observed on acetate agar (Fowell, 1952) after 5 days at $25^{\circ} \mathrm{C}$; vegetative cells transform directly into persistent asci each containing one globose ascospore (Fig. 3).

Glucose and galactose are fermented; sucrose, maltose, lactose and raffinose are not fermented. Glucose, galactose, trehalose (weak, delayed), ethanol (weak, delayed) are assimilated; L-sorbose, sucrose, maltose, cellobiose, lactose, melibiose, raffinose, melezitose, inulin, soluble starch, Dxylose, L-arabinose, D-arabinose, D-ribose, L-rhamnose, D-glucosamine, methanol, glycerol, erythritol, ribitol, galactitol, D-mannitol, D-glucitol, methyl $\alpha$-D-glucoside, salicin, DL-lactic acid, succinic acid, citric acid, inositol and hexadecane are not assimilated. Ammonium sulfate, ethylamine hydrochloride, L-lysine and cadaverine dihydrochloride are assimilated; sodium nitrite and potassium nitrate are not assimilated. Growth in vitamin-free medium is negative. Maximum growth temperature is $37^{\circ} \mathrm{C}$. Starch-like compounds are not produced. Diazonium blue $\mathrm{B}$ reaction is negative. Urease activity is negative. Ubiquinone type is Q-6.
The type strain, AS $2.0706^{\mathrm{T}}\left(=\mathrm{CBS} 10102^{\mathrm{T}}\right)$, was isolated from wastewater collected in a paper mill in north-east China. This strain has been deposited in the CGMCC, Academia Sinica, Beijing, China.

\section{Latin diagnosis of Kazachstania solicola Bai \& Wu sp. nov.}

In medio liquido $\mathrm{YM}$ post dies 3 ad $25^{\circ} \mathrm{C}$, cellulae ovoideae vel subglobosae, $2 \cdot 5-5 \cdot 0 \times 3 \cdot 7-7 \cdot 5 \mu \mathrm{m}$, singulae, binae et adhaerentes. Per gemmationem multipolarem reproducentes. Post 1 mensem sedimentum formatur. In agaro YM post 1 mensem ad $25^{\circ} \mathrm{C}$, butyrosa, cremea, seminitida, glabra cum radiatis, margo glabro vel undulato. In agaro farinae Zea mays post dies 7, pseudohyphae nullae. Asci inconjugatio et conjugatio fiunt. Ascoaporae subglobosae, 1 in quoque asco.

Glucosum et galactosum fermentantur at non sucrosum, maltosum, lactosum nec raffinosum. Glucosum, galactosum, trehalosum (lente), D-ribosum (lente), D-glucosaminum (lente) et glycerolum (lente) assimilantur at non L-sorbosum, sucrosum, maltosum, cellobiosum, lactosum, melibiosum, raffinosum, melezitosum, inulinum, amylum solubile, Dxylosum, L-arabinosum, D-arabinosum, L-rhamnosum, methanolum, ethanolum, erythritolum, ribitolum, galactitolum, D-mannitolum, D-glucitolum, methyl $\alpha$-D-glucosidum, salicinum, acidum DL-lacticum, acidum succinicum, acidum citricum, inositolum nec hexadecanum. Ammonium sulfatum assimilantur at non natrum nitrosum, kalium nitricum, ethylaminum, L-lysinum nec cadaverinum. Ad crescentiam vitaminae externae necessariae sunt. Maxima temperatura crescentiae: $37^{\circ} \mathrm{C}$. Materia amyloidea iodophila non formantur. Diazonium caeruleum B non respondens. Ureum non hydrolysatur. Systema coenzymatis Q-6 adest. Typus depositus in collectione Centraalbureau voor Schimmelcultures, Utrecht, The Netherlands (CBS $6904^{\mathrm{T}}$ ).

\section{Description of Kazachstania solicola Bai \& Wu sp. nov.}

Kazachstania solicola (N.L. n. solicola inhabitant of the soil, referring to the source of the type strain).

In YM broth (Yarrow, 1998), after 3 days at $25^{\circ} \mathrm{C}$, the cells are ovoid to subglobose, $2 \cdot 5-5 \cdot 0 \times 3 \cdot 7-7 \cdot 5 \mu \mathrm{m}$ and occur singly, in pairs or in groups (Fig. 4). Budding is multilateral. After 1 month at $25^{\circ} \mathrm{C}$, sediment is present. On YM agar (Yarrow, 1998), after 1 month at $25^{\circ} \mathrm{C}$, the streak culture is butyrous, cream-coloured, raised, semi-glossy, smooth with faint striations; the margin is entire to slightly undulating. In Dalmau plate culture on corn meal agar, pseudohyphae are not formed. Sporulation is observed on acetate agar (Fowell, 1952) after 7 days at $25^{\circ} \mathrm{C}$, vegetative cells transform directly into persistent asci each containing one subglobose ascospore (Fig. 4).

Glucose and galactose are fermented; sucrose, maltose, lactose and raffinose are not fermented. Glucose, galactose, trehalose (delayed), D-ribose (delayed), D-glucosamine (delayed) and glycerol (delayed) are assimilated; L-sorbose, 

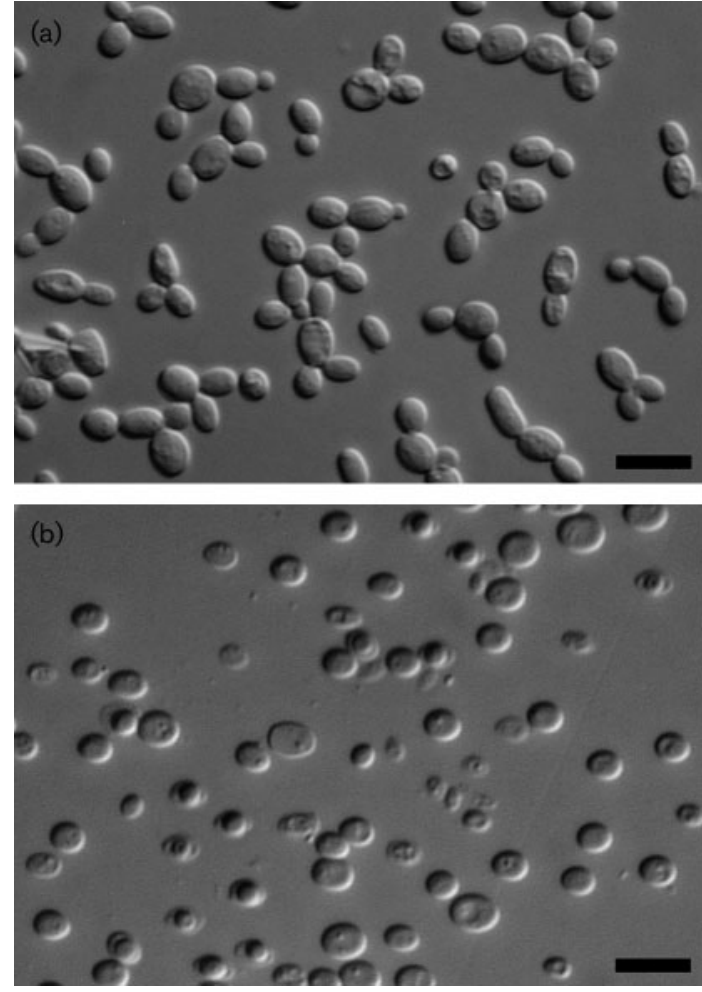

Fig. 4. Kazachstania solicola sp. nov. CBS 6904'. (a) Vegetative cells grown in $\mathrm{YM}$ broth for 3 days at $25^{\circ} \mathrm{C}$. (b) Asci formed on acetate agar after 7 days at $25^{\circ} \mathrm{C}$. Bars, $10 \mu \mathrm{m}$.

sucrose, maltose, cellobiose, lactose, melibiose, raffinose, melezitose, inulin, soluble starch, D-xylose, L-arabinose, D-arabinose, L-rhamnose, methanol, ethanol, erythritol, ribitol, galactitol, D-mannitol, D-glucitol, methyl $\alpha$-Dglucoside, salicin, DL-lactic acid, succinic acid, citric acid, inositol and hexadecane are not assimilated. Ammonium sulfate is assimilated; sodium nitrite, potassium nitrate, ethylamine hydrochloride, L-lysine and cadaverine dihydrochloride are not assimilated. Growth in vitamin-free medium is negative. Maximum growth temperature is $37^{\circ} \mathrm{C}$. Starch-like compounds are not produced. Diazonium blue $\mathrm{B}$ reaction is negative. Urease activity is negative. Ubiquinone type is Q-6.

The type strain, CBS $6904^{\mathrm{T}}$ (=AS $2.2406^{\mathrm{T}}$ ), was isolated from soil collected from the Elburz Mountains, Iran. This strain has been deposited in the Centraalbureau voor Schimmelcultures, Utrecht, The Netherlands.

\section{Acknowledgements}

This study was supported by grants no. 30470005 from the National Natural Science Foundation of China (NSFC) and no. 2001AA227131 of the ' 863 program' from the Ministry of Science and Technology, China.

\section{References}

Bai, F.-Y., Liang, H.-Y. \& Jia, J.-H. (2000). Taxonomic relationships among the taxa in the Candida guilliermondii complex, as revealed by comparative electrophoretic karyotyping. Int J Syst Evol Microbiol 50, 417-422.

Bai, F.-Y., Zhao, J.-H., Takashima, M., Jia, J.-H., Boekhout, T. \& Nakase, T. (2002). Reclassification of the Sporobolomyces roseus and Sporidiobolus pararoseus complexes, with the description of Sporobolomyces phaffii sp. nov. Int J Syst Evol Microbiol 52, 2309-2314.

Fischer, G., James, S. A., Roberts, I. N., Oliver, S. G. \& Louis, E. J. (2000). Chromosomal evolution in Saccharomyces. Nature 405, 451-454.

Fowell, R. R. (1952). Sodium acetate agar as a sporulation medium for yeast. Nature 170, 578.

James, S. A., Cai, J., Roberts, I. N. \& Collins, M. D. (1997). A phylogenetic analysis of the genus Saccharomyces based on $18 \mathrm{~S}$ rRNA gene sequences: description of Saccharomyces kunashirensis sp. nov. and Saccharomyces martiniae sp. nov. Int J Syst Bacteriol 47, 453-460.

Kurtzman, C. P. (2003). Phylogenetic circumscription of Saccharomyces, Kluyveromyces and other members of the Saccharomycetaceae, and the proposal of the new genera Lachancea, Nakaseomyces, Naumovia, Vanderwaltozyma and Zygotorulaspora. FEMS Yeast Res 4, 233-245.

Kurtzman, C. P. \& Robnett, C. J. (2003). Phylogenetic relationships among yeasts of the 'Saccharomyces complex' determined from multigene sequence analyses. FEMS Yeast Res 3, 417-432.

Lu, H.-Z., Cai, Y., Wu, Z.-W., Jia, J.-H. \& Bai, F.-Y. (2004). Kazachstania aerobia sp. nov., a novel ascomycetous yeast species from aerobically deteriorating corn silage. Int J Syst Evol Microbiol 54, 2431-2435.

Makimura, K., Murayama, Y. S. \& Yamaguchi, H. (1994). Detection of a wide range of medically important fungi by the polymerase chain reaction. J Med Microbiol 40, 358-364.

Mikata, K., Ueda-Nishimura, K. \& Hisatomi, T. (2001). Three new species of Saccharomyces sensu lato van der Walt from Yaku Island in Japan: Saccharomyces naganishii sp. nov., Saccharomyces humaticus sp. nov. and Saccharomyces yakushimaensis sp. nov. Int J Syst Evol Microbiol 51, 2189-2198.

Nakase, T. \& Suzuki, M. (1986). Bullera megalospora, a new species of yeast forming large ballistospores isolated from dead leaves of Oryza sativa, Miscanthus sinensis, and Sasa sp. in Japan. J Gen Appl Microbiol 32, 225-240.

Špírek, M., Yang, J., Groth, C., Petersen, R. F., Langkjær, R. B., Naumova, E. S., Sulo, P., Naumov, G. I. \& Piskur, J. (2003). Highrate evolution of Saccharomyces sensu lato chromosomes. FEMS Yeast Res 3, 363-373.

Sugita, T. \& Nakase, T. (1999). Non-universal usage of the leucine CUG codon and the molecular phylogeny of the genus Candida. Syst Appl Microbiol 22, 79-86.

Vaughan-Martini, A. \& Martini, A. (1998). Saccharomyces dairenesis Naganishi (1917). In The Yeasts, a Taxonomic Study, 4th edn, pp. 363-364. Edited by C. P. Kurtzman \& J. W. Fell. Amsterdam: Elsevier.

Vaughan-Martini, A., Martini, A. \& Cardinali, G. (1993). Electrophoretic karyotyping as a taxonomic tool in the genus Saccharomyces. Antonie van Leeuwenhoek 63, 145-156.

Yamada, Y. \& Kondo, K. (1973). Coenzyme Q system in the classification of the yeast genera Rhodotorula and Cryptococcus and the yeast like genera Sporobolomyces and Rhodosporidium. J Gen Appl Microbiol 19, 59-77. 
Yarrow, D. (1998). Methods for the isolation, maintenance and identification of yeasts. In The Yeasts, a Taxonomic Study, 4th edn, pp. 77-100. Edited by C. P. Kurtzman \& J. W. Fell. Amsterdam: Elsevier. 